Nigerian Journal of Physiological Sciences 23 (1-2): 9-11 OPhysiological Society of Nigeria, 2008

Available online/abstracted at http://www.bioline.org.br/np; www.ajol.info/journals.njps; www.cas.org

\title{
GLUCOSE -6- PHOSPHATE DEHYDROGENASE (G6PD) ACTIVITY AND DEFICIENCY IN A POPULATION OF NIGERIAN MALES RESIDENT IN JOS
}

\author{
O. J. EGESIE, D. E. JOSEPH, I. ISIGUZORO' ${ }^{1}$, U. G. EGESIE ${ }^{2}$
}

\author{
Departments of Haematology and Blood Transfusion, Jos University Teaching Hospital, Jos. \\ 1Chemical Pathology, Jos University Teaching Hospital, Jos, Nigeria, \\ 2 Human Physiology, Faculty of Medical Sciences, University of Jos, Nigeria. \\ Email: juliegesie@yahoo.com,egesiej@unijos.edu.ng
}

\begin{abstract}
Summary: The activity of red blood cell Glucose 6-phosphate dehydrogenase (G6PD) in one hundred and twenty six healthy male individuals who are Nigerians residing in Jos was evaluated. The enzyme activity was determined quantitatively by spectrophotometer assay method. The activity of red cell G6PD enzyme was subnormal in $20 \%$ of the population studied. This agrees with previous report of the prevalence of G6PD deficiency in Nigerian males from the Western region of the country which is between 20 and $26 \%$. The proportion of Nigerian males with subnormal G6PD activity is relatively constant irrespective of their geographical location.
\end{abstract}

Key words: G6PD activity, males, Nigerians.

\section{Introduction}

Glucose-6-phosphate dehydrogenase (G6PD) is a cytoplasmic enzyme that is distributed widely in all cells. It catalyses the first step in the hexose monophosphate pathway, producing nicotinamide adenosine dinucleotide phosphate in the reduced form (NADPH) (Luzzatto, 2001). This co-enzyme is required as hydrogen donor for numerous reductive processes of various biochemical pathways as well as for the stability of catalase and the preservation and regeneration of the reduced form of glutathione (Luzzatto, 1995). Catalase and glutathione are both essential for the detoxification of hydrogen peroxide and free radicals generated during the normal cellular metabolic processes (Luzzatto, 2001). The defence of cells against hydrogen peroxide, free radicals and other forms of oxidative stress, therefore, ultimately and heavily depend on G6PD for the generation of NADPH. The red cells are exquisitely sensitive to oxidative damage in the absence or reduced activity of G6PD as they lack other NADPH-producing enzymes (Luzzatto 1995).

G6PD deficiency resulting in decreased activity of the enzyme is the most common enzymopathy known worldwide with about 400 million people affected (Mason 1996). In Nigerians, the prevalence of G6PD deficiency ranges from $4-26 \%$ with the male population having about $20-26 \%$ (Luzzatto 2001, Ademowo 2002). This prevalence rate varies from one community to another. The paucity of reported information on the pattern of distribution of G6PD activity and the proportion of G6PD deficient male individuals in our locality have prompted the need to embark on this study. We therefore report G6PD activity and deficiency in a population of Nigerian males resident in Jos.

\section{Materials and methods Subjects}

One hundred and twenty six (126) consecutive healthy male blood donors at the blood bank unit of the Jos University Teaching Hospital who were resident in Jos and gave their consent were studied. They were aged between 20 and 49 years and all Nigerians irrespective of tribe.

Sample collection

Two millilitres of blood were collected using aseptic procedure from the most prominent peripheral vein in the antecubital fossa of each subject. The blood was emptied into Ethylene diamine tetra acetic acid (EDTA) bottle and gently mixed. The blood sample was then stored at $4^{0} \mathrm{C}$ in a refrigerator till required for use. All blood samples collected were analysed within 48 hours of collection. 
Determination of G6PD activity

G6PD activity was determined by quantitative assay of the enzyme activity in erythrocytes based on the Sigma Diagnostic procedure for quantitative determination of G6PD using Sigma Diagnostic kit (Sigma-Aldrich co. St Louise, USA). Decreased activity or G6PD deficiency was taken as any level of enzyme activity less than $4.6 \mathrm{I}$.U/g haemoglobin (reference range 4.6 - $13.5 \mathrm{IU} / \mathrm{g}$ haemoglobin) (Sigma Diagnostic Procedure 2001).

Calculation of G6PD enzyme activity in erythrocytes

$\Delta \mathrm{A}$ per min $=$ final $\mathrm{A}-$ initial $\mathrm{A} \div 5, \mathrm{G} 6 \mathrm{PD}$

$(\mathrm{IU} / \mathrm{gHb})=\Delta \mathrm{A} / \mathrm{min} \mathrm{X} 4839 \mathrm{X} \mathrm{tcf} \div \mathrm{Hb}(\mathrm{g} / \mathrm{dl})$

Where tcf is temperature correction factor, $\mathrm{A}=$ absorbance at $340 \mathrm{~nm}$ wavelength, $\Delta=$ change in absorbance

Haemoglobin concentration was determined using an automated coulter counter. Statistical analyses were determined using statistical software epi-info computer package. Results were expressed as mean $\pm \mathrm{SD}$ and presented in tables.

\section{Results}

Table 1 shows the age distribution of the subjects studied. Majority $(80 \%)$ of the subjects had normal enzyme activity ranging from 5.25 to $14.27 \mathrm{IU} / \mathrm{gHb}$. However, a small proportion (20\%) had subnormal enzyme activity with G6PD activity ranging between 2.25 to $4.43 \mathrm{IU} / \mathrm{gHb}$. (Table 2). The age distribution of the individuals that have reduced or deficient G6PD activity is summarized in Table 3.

Table 1: Age distribution of subjects studied

\begin{tabular}{ll}
\hline Age (years) & No of subjects \\
$20-24$ & $42(33.3 \%)$ \\
$225-29$ & $34(27.0 \%)$ \\
$30-34$ & $24(19.0 \%)$ \\
$35-39$ & $8(6.3 \%)$ \\
$40-44$ & $12(9.5 \%)$ \\
\hline
\end{tabular}

Table 2: Subjects and their G6PD activity

\begin{tabular}{llll}
\hline$n$ & $\begin{array}{l}\text { G6PD activity } \\
\text { level }(I U / g H b)\end{array}$ & G6PD status & $\%$ \\
26 & $3.34 \pm 1.09$ & Deficient & 20 \\
100 & $9.76 \pm 4.51$ & Normal & 80 \\
\hline
\end{tabular}

Table 3: Age distribution of G6PD deficient subjects

\begin{tabular}{llc}
\hline Age(years) & $n$ & Percentage \\
$20-24$ & 4 & 15.4 \\
$25-29$ & 6 & 23.0 \\
$30-34$ & 4 & 15.4 \\
$35-39$ & 6 & 23.0 \\
$40-44$ & 2 & 7.7 \\
$45-49$ & 4 & 15.4 \\
Total & 26 & 100 \\
\hline
\end{tabular}

\section{Discussion}

The prevalence of glucose 6-phosphate dehydrogenase (G6PD) deficiency in Nigerians has been put at $4-26 \%$ and $20-26 \%$ among male Nigerians (Luzzatto 1975). Much of the work culminating in the report of G6PD activity and deficiency was done in the mid 1970s and 1980s from the South Western region of Nigeria; although isolated report of G6PD deficiency in specific clinical conditions were made from the North Eastern region of Nigeria (Tugwell, 1973), very limited report of G6PD activity and deficiency in healthy population in the North Central region of Nigeria is available as far as the authors are aware.

In this study, $20 \%$ of the subjects studied had G6PD enzyme activity below the normal reference range and so are G6PD deficient. This proportion of G6PD deficient individuals fall within the range reported for Nigerians from other parts of the country and collaborates with the report from a community in South Western part of Nigeria in male individuals studied (Ademowo and Falusi 2002). It may then be that the prevalence of G6PD deficiency among Nigerian males irrespective of their geographical location is relatively constant. This study confirms the prevalence rate of $20 \%$ of Nigerian males deficient in G6PD.

G6PD deficiency is beneficial as it is known that red cells that are deficient in G6PD are resistant to Plasmodium falciparum invasion since the parasite require the enzyme for its normal survival in the host cell (Ruwende 1995, Tishkoff 2001). This deficiency offers a selective protection against P.falciparum malaria (Roth et al, 1983). It has, however, been reported that some P.falciparum parasite strains have been able to synthesize their own G6PD enzyme thereby 
evading the immunity offered by G6PD deficiency in such individuals (Usanga and Luzzatto 1985). G6PD deficiency is also known to be associated with decreased phagocytic and bactericidal activity of phagocytes (Owusu 1978, Luzzatto 1975). This may predispose G6PD deficient individuals to increased bacterial infections.

G6PD deficient individuals are asymptomatic until they are exposed to oxidative stress. Oxidative stress which results in acute haemolytic anaemia include ingestion of drugs among other factors such as infection, chemicals and ingestion of some food stuffs (Luzzatto 1975). It may then be necessary for males in our locality to know their G6PD status so that those found to be deficient can avoid the trigger factors for acute haemolytic attack such as indiscriminate ingestion of drugs.

\section{Acknowledgement}

We are grateful to the staff of Haematology and Blood Transfusion and Chemical Pathology Departments of Jos University Teaching Hospital for their assistance in blood sampling and assay of G6PD activity. We are also grateful to Mrs Enei Yakubu (USA) for providing the reagent for the study.

\section{References}

Ademowo O G and Falusi A G.(2002). Molecular Epidemiology and activity of erythrocyte G6PD variants in a homogeneous Nigerian population. East Afr. Med. J. 79: 42-44.

Luzzatto L and Gordon-Smith E C. (2001). Inherited haemolytic anaemia. In: Postgraduate Haematology. Hoffbrand AV, Lewis SM and Tuddenham EGD (eds) $4^{\text {th }}$ edition. Arnold, London. Pp 120-143.

Luzzatto L. (1995). G6PD deficiency and the pentose phosphate pathway. In: Blood: principles and practise of Haematology by Handin R I, Lux S E, and Stossel T P (eds). J B Lippincott Company, Philadelphia. Pp 1897-1923.
Luzzatto L. (1975). Inherited haemolytic states: G6PD deficiency. Clinics in Haematology. 83-108.

Mason J P. (1996). New insight into G6PD deficiency. Br. J. Haematol. 585-591.

Owusu S K. (1978). Clinical manifestation of G6PD deficiency in Ghana. Ghana Med J. 233-239.

Roth E F Jr, Raventos-Suarez C, Rinaldi A, Nagel R L. (1983). Glucose-6-phosphate dehydrogenase deficiency inhibits invitro growth of Plasmodium falciparum. Proc Natl Acad Sci USA. 80: 298-299.

Ruwende C, Khoo S C, Snow R W, Yates S N, Kwiatkowski D, Gupta S, Warn P, Allsopp C E, Gilbert S C, Peschu N. (1995). Natural selection of hemi- and heterozygotes for G6PD deficiency in Africa by resistance to severe malaria. Nature. 376: 246-249.

Sigma Diagnostics. (2001). Glucose-6-phosphate dehydrogenase (G6PDH) procedure number 345uv. (Revised): 1E-3E.

Tishkoff S A, Varkonyi R, Cahinhinan N, Abbes S, Argyropoulos G, Destro-Bisol G, Drousiotou A, Dangerfield B, Lefranc G, Loiselet J, Piro A, Stoneking M, Tagarelli A, Tagarelli G, Touma E H, Williams S M, Clark A G. (2001). Haplotype diversity and linkage disequilibrium at human G6PD: recent origin of alleles that confer malarial resistance. Science. 293: 455-462.

Tugwell P. (1973). Glucose-6-phosphate dehydrogenase deficiency in Nigerians with jaundice associated with lobar pneumonia. Lancet. 968-970.

Usanga E A and Luzzatto L. (1985). Adaptation to glucose-6-phosphate dehydrogenase-deficient host red cells by production of parasites encoded enzyme. Nature. 313: 793-795. 